\title{
Comparison of the Oxygen Diffusing Capacity of the Picui Ground Dove (Columbina picui) with Other Doves of Chile
}

\author{
Comparación de la Capacidad de Difusión de Oxígeno de la \\ Tórtola Picus (Columbina picui) con Otras Tórtolas de Chile
}

"Carmen Alfaro; "Daniela Figueroa Perez; *," Pablo Sabat K.; "Michel Sallaberry \& * Mauricio Canals L.

\begin{abstract}
ALFARO, C.; FIGUEROA, D. P.; SABAT, P.; SALLABERRY, M. \& CANALS, M. Comparison of the oxygen diffusing capacity of the Picui Ground Gove (Columbina picui) with other doves of Chile. Int. J. Morphol., 28(1):127-133, 2010.

SUMMARY: We studied the respiratory surface density and the thickness of the air-blood barrier in the Picui Ground Dove (Columbina picui), and compared it with Eared Dove (Zenaida auriculata) and Blacked-winged Ground Dove (Metropelia melanoptera), two larger species. As expected, Columbina picui $\mathrm{BMR}$ and $\mathrm{VO}_{2}$ max showed higher values than those of the larger species according to the expected for their body size. The respiratory surface density and the thickness of the blood-air barrier were not different among the different species of doves. However C. picui showed an anatomical diffusion factor lower than M. melanoptera and Z. auriculata. Picui Ground Dove had low values of oxygen diffusion capacity, such as cursorial birds. A differential oxygen partial pressure of $7.5 \mathrm{Kpa}$, an usual value at sea level, it can hardly meet their maximal energy requirements and it means that Picui Ground Dove, would have serious limitations to live at high altitudes, which is consistent with the observation that this species inhabits lowlands and at the foot hills of the Andes.
\end{abstract}

KEY WORDS: Picui ground gove; Columbina picui; Metropelia melanoptera; Zenaida auriculata; Oxygen diffusing.

\section{INTRODUCTION}

Pigeons and Doves are included in the family Columbidae, order Columbiformes. These are a very diverse family of birds found from the tropics to the deserts from high to low altitudes (Jaramillo, 2003; Steadman, 1997). Their greatest diversity is found in tropical rainforests with lots of species in Colombia and New Guinea (McNab, 2000). While their food in tropical areas ranges from seeds to fruits; in temperate areas and deserts they are mainly granivores (Frith et al., 1976). These birds are good flyers, with strong beat flight, being recognized the athletic ability of the domestic pigeon (Peters et al., 2005). In Chile there are 10 species of Columbidae whose sizes range from $17 \mathrm{~cm}$ and $30 \mathrm{~g}$ in the species of the genus Columbina and some Metriopelia especies to more than $36 \mathrm{~cm}$ and $340 \mathrm{~g}$ in Rock Dove (Columba libia) and Chilean Pigeon (Patagioenas araucana). They feed on seeds and can be found from sea level to high altitude. Some species such as Metriopelia melanoptera and Metriopelia ceciliae can be found over 3500 meters in altitude (Jaramillo).
Small size and flight condition impose high energetic requirements in birds and mammals (Maina, 2000; Canals et al., 2001; Iriarte-Díaz et al., 2002; Canals et al., 2005a; 2005b; Canals et al., 2007, 2008) and this high energetic demand can affect morphological and hematological parameters of the lungs in birds and mammals (Canals et al., 2005c; Figueroa et al., 2007). Of all the different components of the respiratory chain, pulmonary diffusion is the only variable that exclusively depends on morphometric intrapulmonary parameters (Weibel, 1998). Oxygen flow is directly related to the oxygen partial pressure gradient between the alveoli and blood capillaries, and the oxygen diffusion capacity $\left(\mathrm{D}_{\mathrm{O} 2}\right)$ (Weibel, 1970/71; Maina, 2002). The latter is determined by the ratio between the respiratory surface area $\left(\mathrm{S}_{\mathrm{r}}\right)$ and the harmonic mean thickness of the air-blood barrier (th) (Weibel, 1970/71; Gehr et al., 1981; Maina \& King, 1984; Maina et al., 1991; Maina, 2002). Since $S_{\mathrm{r}}$ may be expressed as the product of the volume of the exchange

*Departamento de Ciencias Ecológicas, Facultad de Ciencias, Universidad de Chile, Casilla 653, Santiago-Chile. e-mail: mcanals@uchile.cl ${ }^{*}$ Center for Advanced Studies in Ecology \& Biodiversity and Departamento de Ciencias Ecológicas, Facultad de Ciencias, Universidad de Chile, Casilla 653, Santiago-Chile.e-mail: psabat@uchile.cl 
lung tissue $\left(\mathrm{V}_{\mathrm{LE}}\right)$, the respiratory surface density $\left(\mathrm{RS}_{\mathrm{d}}\right)$, and Krogh's permeation coefficient (k) (Gehr et al.; Maina, 2002) the oxygen conductance $\left(\mathrm{D}_{\mathrm{t}} \mathrm{O}_{2}\right)$ may only be modified by changes in $\mathrm{V}_{\mathrm{LE}}, \mathrm{RS}_{\mathrm{d}}$ or

$$
\text { th:.. } D_{t} O_{2}=\frac{S_{r}}{\tau_{h}}=K \frac{R S_{d} \cdot V_{L E}}{\tau_{h}}
$$

There is evidence that birds and bats optimize oxygen flow, the respiratory morphology in birds (see Maina, 2002) and the bronchial tree of bats being outstanding examples of this (Maina, 2000; Canals et al., 2008). In the lungs, the respiratory surface density of bats appears to be slightly lower than that of non-flying mammals, but much lower than that of birds. Also, the harmonic mean thickness of the blood-gas barrier in bats is slightly thinner than that of non-flying mammals, yet thicker than that of birds (Maina, 2000). In birds, the lung volume is lower than that of non-flying mammals, while bat lungs show the opposite trend. High respiratory surface density and a thin air-blood barrier have been reported in several small bird species, such as Sparkling Violater (Colibri coruscans) (Dubach, 1981) while the Orders containing non-flying birds or birds that fly occasionally (e.g., Sphenisciformes, and Galliformes or Struthioformes), appear to have a thicker blood-gas barrier than flying birds (Maina, 2002; Canals et al., 2007; Figueroa et al.).

Regarding doves and pigeons, high oxygen diffusion capacity in Columba libia (Maina, 2000) and Zenaida auriculata have been reported, which in the latter species is also associated with smaller red blood cells than the cursorial species Nothoprocta perdicaria (Chilean Tinamu) (Canals et al., 2007; Figueroa et al.). One might expect then that species of pigeons with increased energy requirements such as those living in high altitudes or with very small body size, would have high oxygen diffusion capacities. The aim of this study is to estimate the efficiency in the lung oxygen conduction in the small Picui Ground Dove (Columbina picui), and to compare it with two large native species of Chile: the Black-winged Ground Dove (Metriopelia melanoptera) which inhabits high altitudes from Tarapacá to Aysen, and the Eared Dove (Zenaida auriculata) that can be found from Tarapacá to Tierra del Fuego, from the coast to 2000 masl(Jaramillo).

\section{MATERIAL AND METHOD}

Animal models and capture sites. Ten individuals of the species Zenaida auriculata $(\mathrm{n}=4 ; \mathrm{Mb}=129.9 \pm 12.7 \mathrm{~g})$,
Columbina picui $(\mathrm{n}=4 ; \mathrm{Mb}=39.9 \pm 1.4 \mathrm{~g})$ and Metriopelia melanoptera $(\mathrm{n}=2 ; \mathrm{Mb}=78.4 \pm 2.4 \mathrm{~g})$ were captured with mist nets, between September and December, 2008.

Zenaida auriculata (Eared Dove): Collected at Quebrada de la Plata, Maipú, in central Chile, (332 $27^{`} \mathrm{~S}$, $\left.70^{\circ} 42^{`} \mathrm{~W}, 1.500 \mathrm{masl}\right)$. Distribution: A common and widespread dove is found in a variety of habitats. Urban areas particularly parks and gardens as well as forest edge, agricultural areas, desert oases and matorral. From Arica to Tierra del Fuego, 0 -2.500 masl (Jaramillo).

Columbina picui (Picui Ground Dove): Collected at Santo Domingo, in the coast of Central Chile (3339's, 71³6 $\mathrm{W}$, 30 masl). Distribution: Common in dry, open matorral and agricultural areas. Often seen in rural towns and parks. From Copiapo to Valdivia, 0-1500 masl (Jaramillo).

Metriopelia melanoptera (Black-winged Ground Dove): Collected at Farellones in the Andes Mountains of Central Chile (3320'S; 70¹8'W, 2.390 masl). Distribution: Widespread, occupying a variety of habitats. Dry shrubby puna in north, Andean scrub in central zone, and even open matorral in winter, scrubby highland in extreme south. Mainly 1000 - 4000 masl, but sometimes to sea level (winter) (Jaramillo).

The animals were taken to the laboratory, where they were kept at room temperature with food (seeds) and water ad lib.

\section{Oxygen consumption.}

Basal metabolic rate. All measures of oxygen consumption $\left(\dot{V}_{2}\right)$ were performed in an open-flow respirometer system (Sable Systems). Individual determinations of basal metabolic rate were performed in steel chambers at a thermoneutral $\left(30^{\circ} \mathrm{C}\right)$ temperature (Figueroa et al.). The metabolic chambers received dry air at a rate of $500 \mathrm{ml} / \mathrm{min}$ from a flow controller (Sierra Instruments), to assure an adequate air mix. $\mathrm{CO}_{2}$ was removed and the air was dried before entering and after leaving the chamber. Oxygen was monitored every $5 \mathrm{sec}$ using an Oxygen Analyzer 1FC-1B (Sable Systems). Oxygen consumption was estimated using the equation of Withers (1977). Measurements were then made during the resting phase of the species.

Maximum thermogenic oxygen consumption ( $\left.\mathrm{V}_{2}\right)$. Maximum thermogenic oxygen consumption was determined in an atmosphere of $\mathrm{He}-\mathrm{O}_{2}(80-20 \%)$ in an open circuit respirometer (Rosenmann \& Morrison, 1974). The metabolic chamber received dried air at $1000 \mathrm{mLmin}^{-1}$ from 
a mass flow controller and through Bev-A-Line tubing (Thermoplastic Processes Inc.); furthermore, the chamber temperature was constantly monitored $\left(5.0 \pm 0.5^{\circ} \mathrm{C}\right)$. This flow kept the partial oxygen pressure above 150 Torr, which is considerably above the level of hypoxia. The gas mixture was passed through $\mathrm{CO}_{2}$ (Baralyme \& Drierite) at the entrance and exit of the chamber. To be sure that individuals $\dot{V} O_{2 \max }$ reached, measurements were stopped when the reduction of $\dot{V} O_{2 \max }$ was evident; hypothermia was checked with a Cole-Parmer copper-constatan thermocouple after each measurement.

Pulmonary structure. After the metabolic experiments, individuals were euthanized using $\mathrm{CO}_{2}$, complying with the current laws of Chile and the standards of the Ethical Committee of the Facultad de Ciencias, Universidad de Chile, where the experiments were performed. A small tracheotomy was performed and the lungs instilled with a $2.5 \%$ glutaraldehyde in a $0.01 \mathrm{~mol} \mathrm{~L}^{-1}$ phosphate buffer solution $(\mathrm{pH}=7.4,350 \mathrm{mOsm})$ using a plastic catheter with the reservoir located $20 \mathrm{~cm}$ above the level of the sternum. The trachea was ligated to maintain the intrapulmonary fixative volume.

Immediately following this procedure, the lungs were removed and immersed in the same fixative solution at $4^{\circ} \mathrm{C}$ for a minimum of 2 hours. Next, tissues (right and left lungs) were processed for routine light microscopy (LM) and transmission electron microscopy (TEM). Briefly, two pieces of 1-2 mm thickness (one for LM and one for TEM) were obtained from each one of three zones (upper, middle and basal) in each lung. The pieces were washed with buffer and post-fixed with $1 \%$ osmium tetraoxide for 1 hour at $4^{\circ} \mathrm{C}$. For light microscopy, slices were dehydrated in ascending series of ethanol and infiltrated and embedded in epoxy resin constructing cubes of 2-3 $\mathrm{mm}^{3}$, obtaining semi-thin randomly oriented sections of $1 \mu \mathrm{m}$. Tissue samples were stained with $1 \%$ toluidine blue and viewed with a microscope. For TEM, the pieces were stained with $1 \%$ osmium tetroxide, en bloc stained with $2 \%$ uranyl acetate, and dehydrated in ascending series of alcohol. Ultrathin sections of 60-90 nm of thickness were made, contrasted with $\mathrm{Pb}$-citrate and mounted on copper mesh grids and viewed in a JOEL/JEM 100SX transmission electron microscope. Sections were photographed and digitalized, and twelve semi-thin and twelve ultra-thin sections per individual were analyzed using Scion Image Software.

The respiratory surface density $\left(\mathrm{RS}_{\mathrm{d}}\right)$ was estimated by means of the line-intersection stereological method (Weibel 1970/71) in the semi thin sections with light microscopy at 10X magnification:

$$
R S_{d}=\frac{2 I}{1 / 2 \cdot P_{T} \cdot Z}
$$

where $\mathrm{I}$ is the number of intersections between line probes of length $\mathrm{Z}$ with the respiratory surface, and $\mathrm{P}_{\mathrm{T}}$ is the number of testing points. The number of line segments was $1 / 2$ the number of points.

The harmonic mean thickness of the air-blood barrier (th) was estimated by a stereological method in a square lattice grid as suggested by Weibel (1970/71) and Maina (2002):

$$
\frac{1}{\tau_{h}}=\frac{3}{2} \cdot \frac{\sum_{j=1}^{m} f_{j} \cdot \frac{1}{l_{j}}}{\sum_{j=1}^{m} f_{j}}
$$

where $l_{j}$ is the mid-value of the intercept length of linear probes (on the direction of the line), $\mathrm{f}_{\mathrm{j}}$ the frequency of class $\mathrm{j}$, and $\mathrm{m}$ is the number of classes.

The thickness of the air-blood barrier, the density of the respiratory surface and the lung volume allowed the estimation of the oxygen diffusion capacity. The lung volume was estimated by the allometric relationship:

$$
V_{L}=29.6 M b^{0.94}
$$

(Schmidt-Nielsen, 1984). The parenchymal lung volume was estimated as

$$
V p=0.46 \cdot V_{L}
$$

(Maina, 2002). From these structural measurements the morphometric oxygen diffusion capacity (tissue) was estimated using:

$$
D_{t} O_{2}=\kappa \frac{R S_{d} \cdot V p}{\tau_{h}}
$$

where $\mathrm{D}_{t} \mathrm{O}_{2}$ is the oxygen diffusion capacity of the alveolocapillary barrier (tissue), and $\mathrm{k}$ is the Krogh's diffusion coefficient $K=4.1 \cdot 10^{-10} \mathrm{~cm}^{2} \mathrm{~s}^{-1} \mathrm{mbar}^{-1}=4.1 \cdot 10^{-12} \mathrm{~cm}^{2} \cdot \mathrm{s}^{-1} \cdot \mathrm{Pa}^{-1}$ (Gehr et al.). RS $\mathrm{d}_{\mathrm{d}}$ is the respiratory surface density, $\mathrm{Vp}$ is the parenchymal lung volume, and th is the harmonic mean thickness of the blood-gas barrier.

Analysis. The respiratory surface density and the thickness of the air-blood barrier in the different species were studied with repeated measures ANOVA. The anatomical diffusion factors $\left(\mathrm{ADF}=\mathrm{RS}_{\mathrm{d}} / \mathrm{t}_{\mathrm{h}}\right)$ was studied with Kruskal-Wallis test. Basal metabolism and $\mathrm{VO}_{2}$ max of C. picui was only compared with those of $Z$. auriculata because an individual M. melanoptera died prior to its study. 


\section{RESULTS}

As expected, Columbina picui showed a higher BMR and $\mathrm{VO}_{2}$ max than the larger species $(\mathrm{U}=0, \mathrm{z}=2.3, \mathrm{p}=0.02$ and $\mathrm{U}=1, \mathrm{z}=2.0, \mathrm{p}=0.04$ for $\mathrm{BMR}$ and $\mathrm{VO}_{2} \max$, respectively) (Fig. 1). However all species studied showed BMR and $\mathrm{VO}_{2}$ max according to the expected for their body size (Table I) and the ratio observed / expected was not different between them $(\mathrm{U}=4, \mathrm{z}=1.15$ and $\mathrm{U}=5, \mathrm{p}=0.86$, $\mathrm{p}>0.05$ for $\mathrm{BMR}$ and $\mathrm{VO}_{2}$ max respectively).
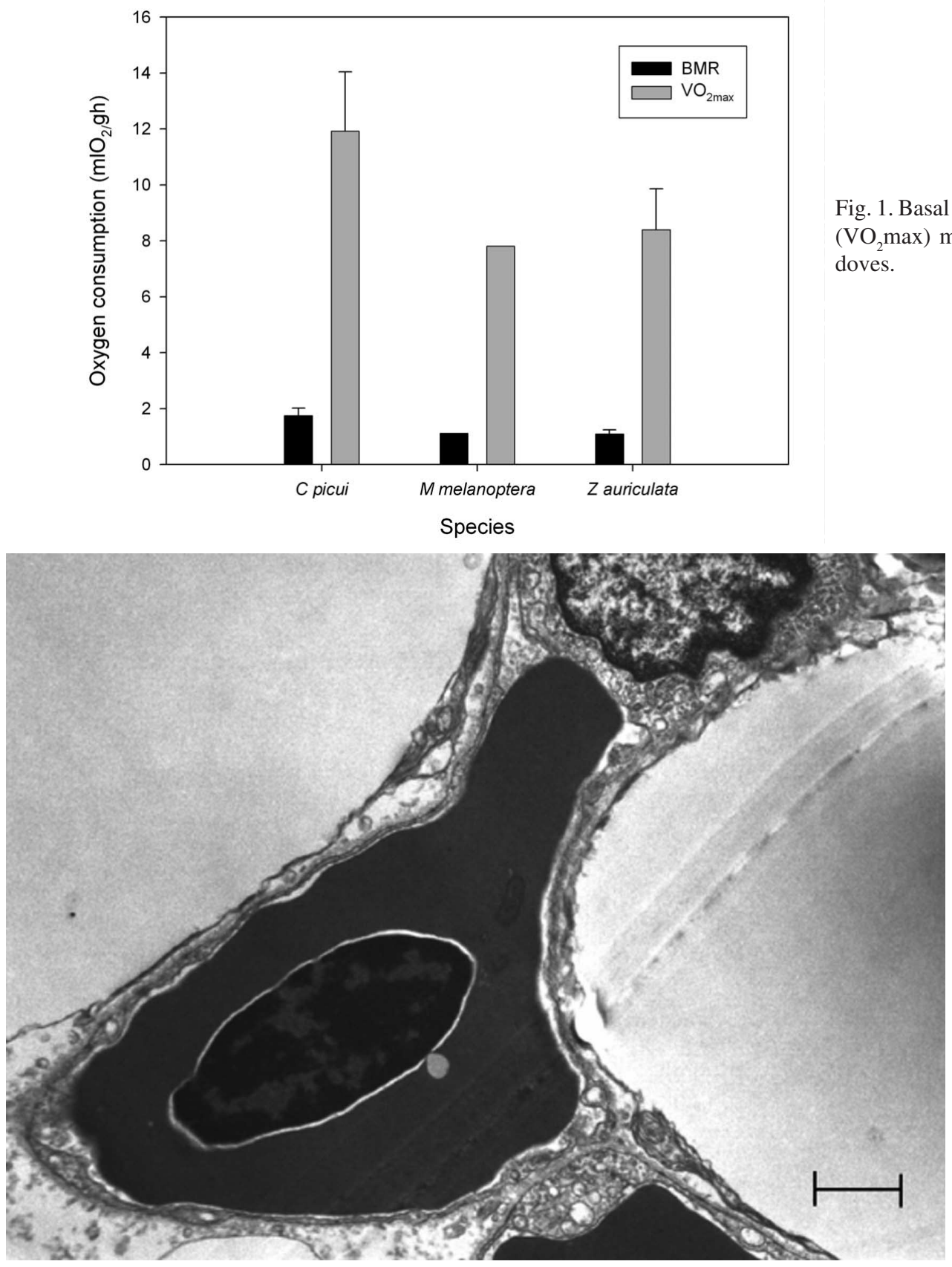

The respiratory surface density and the thickness of the blood-air barrier (Fig. 2) were not different among the different species of doves $(\mathrm{L}-\mathrm{Wilks}=0.027, \mathrm{~F} 14,2=0.73$, $\mathrm{p}=0.71$; -Wilks $\mathrm{L}=0.294, \mathrm{~F} 10,6=0.50, \mathrm{p}=0.84$, respectively). However $C$. picui showed an anamical diffusion factor lower than M. melanoptera and Z. auriculata $\left(c^{2}=8, p=0.0183\right)($ Table I).
Fig. 1. Basal (BMR) and maximum $\left(\mathrm{VO}_{2} \max \right)$ metabolic rate of three doves.
Fig. 2. Electron micrograph of gas exchange tissue of Columbina picui (6000X). Scale bar $1 \mu \mathrm{m}$. The picture shows a red cell in a blood capillary, the air-blood barrier and two air capillaries. 
ALFARO, C.; FIGUEROA, D. P.; SABAT, P.; SALLABERRY, M. \& CANALS, M. Comparison of the oxygen diffusing capacity of the Picui Ground Gove (Columbina picui) with other doves of Chile. Int. J. Morphol., 28(1):127-133, 2010.

Table I. Metabolic and lung morphometric parameters in three doves. BMR = basal metabolic rate; $\mathrm{O} / \mathrm{E}-\mathrm{BMR}=\mathrm{observed} / \mathrm{expected} \mathrm{ratio}$ of BMR; $\mathrm{VO} 2 \mathrm{max}=$ maximum metabolic rate; O/E-VO2max = observed/expected ratio of $\mathrm{VO}_{2} \mathrm{max} ; \mathrm{t}_{\mathrm{h}}=$ thickness of the air-blood barrier; $\mathrm{RS}^{\mathrm{d}}=$ respiratory surface density; $\mathrm{ADF}=$ anatomic diffusion factor; $\mathrm{Vl}=$ lung volume; $\mathrm{RS}=$ respiratory surface; $\mathrm{DtO} \mathrm{F}_{2}=\mathrm{oxygen}$ diffusion capacity (tissue); DTO2/Mb = mass-specific oxygen diffusion capacity (tissue) and Sf = safety factor.

\begin{tabular}{|c|c|c|c|}
\hline & C. picui & M. melanoptera & Z. auriculata \\
\hline $\mathrm{BMR}\left(\mathrm{mlO}_{2} / \mathrm{gh}\right)$ & $1.75 \pm 0.26$ & 1.12 & $1.10 \pm 0.14$ \\
\hline $\mathrm{O} / \mathrm{E}-\mathrm{BMR}$ & $1.049 \pm 0.161$ & 0.803 & $0.913 \pm 0.120$ \\
\hline $\mathrm{VO}_{2} \max \left(\mathrm{mlO}_{2} / \mathrm{gh}\right)$ & $11.92 \pm 2.12$ & 7.81 & $8.40 \pm 1.47$ \\
\hline $\mathrm{O} / \mathrm{E}-\mathrm{VO}_{2} \max$ & $0.924 \pm 0.152$ & 0.787 & $1.049 \pm 0.222$ \\
\hline $\mathrm{h}(\mathrm{m})$ & $0.302 \pm 0.118$ & $0.186 \pm 0.008$ & $0.169 \pm 0.013$ \\
\hline $\mathrm{RS}_{\mathrm{d}}\left(\mathrm{cm}^{-1}\right)$ & $2328.9 \pm 426.4$ & $2580.4 \pm 190.3$ & $2098.5 \pm 263.4$ \\
\hline $\operatorname{ADF}\left(\mathrm{m}^{-1}\right)$ & $0.404 \pm 0.145^{\mathrm{a}}$ & $1.346 \pm 0.001^{\mathrm{b}}$ & $2.087 \pm 0.620^{\mathrm{c}}$ \\
\hline $\mathrm{V} 1(\mathrm{ml})$ & $1.04 \pm 0.04$ & $2.11 \pm 0.07$ & $3.58 \pm 0.37$ \\
\hline $\mathrm{RS}\left(\mathrm{cm}^{2}\right)$ & $1111.2 \pm 192.8$ & $2497.4 \pm 104.0$ & $3477.7 \pm 763.6$ \\
\hline DTO2 $\left(\mathrm{mlO}_{2} / \mathrm{sPa}\right)$ & $0.00017 \pm 0.00006$ & $0.00055 \pm 0.00000$ & $0.00086 \pm 0.00025$ \\
\hline $\mathrm{DTO} 2 / \mathrm{Mb}\left(10^{-6}\right.$ & $4.19 \pm 1.6$ & $7.04 \pm 0.22$ & $6.51 \pm 1.29$ \\
\hline $\mathrm{PO}^{*} *(\mathrm{kPa})$ & $8.9 \pm 3.9$ & 3.0 & $3.6 \pm 0.68$ \\
\hline$\overline{\mathrm{S} f}$ & $0.949 \pm 0.332$ & 2.487 & $2.111 \pm 0.360$ \\
\hline
\end{tabular}

\section{DISCUSSION}

It has been suggested that climate, body mass and species distribution would affect the metabolic rate of the doves. McNab found metabolic differences between continental and island species, and between species of tropical and temperate climates. The species studied in this study, although all continental, show significant differences in habitat, but while Picui Ground Doves showed a higher metabolism than larger species, this difference is attributable only to the difference in body size. When corrected for body size, both the basal metabolism and $\mathrm{VO}_{2} \max$ were similar in the three species.

No differences were found in the thickness of the air-blood barrier or in the respiratory surface density. However, the anatomical diffusion factor was different in these three species, being the lowest value of Picui Ground Dove, indicating that this species has a slightly lower refined lung in relation to other species. This result was expected since Zenaida auriculata is a good flying species with high energetic requirements (Canals et al., 2007) and Metriopelia melanoptera is a species that lives preferently at high altitudes while Picui Ground Dove is a species that spends much of its time foraging seeds on the ground (Jaramillo).

When we consider the oxygen diffusing capacity in the three species we observed that the larger species $(Z$. auriculata and M. melanoptera) have high values similar to those reported for Z. auriculata (Figueroa et al.) and close to those of the common pigeon Columba libia. However, Picui Ground Dove had low values, such as cursorial birds. Considering the allometric relationship for the total oxygen diffusion capacity from air to red cells $\left(\mathrm{D}_{\mathrm{L}} \mathrm{O}_{2}\right)$ in birds:

$$
\mathrm{D}_{\mathrm{L}} \mathrm{O}_{2}=7.19 \cdot M b^{0.9198}
$$

with $\mathrm{M}_{\mathrm{b}}$ in grams and $\mathrm{D}_{\mathrm{L}} \mathrm{O}_{2}$ in $\mathrm{mm}^{3} / \mathrm{min} \mathrm{mmHg}$ and the observation that $\mathrm{D}_{\mathrm{L}} \mathrm{O}_{2}$ is about $1 / 10 \mathrm{D}_{\mathrm{t}} \mathrm{O}_{2}$ (Canals et al., 2005b; Figueroa et al.) we estimated the expected $\mathrm{D}_{\mathrm{t}} \mathrm{O}_{2}$ for our species. While for Z. auriculata and M. melanoptera $\mathrm{D}_{t} \mathrm{O}_{2}$ were $82.7 \pm$ $17.0 \%$ and $85.9 \pm 2.5 \%$ of the expected value, for $C$. picui it was only $48.4 \pm 18.5 \%$ of the expected value. This can be seen in a better way analyzing the safety factors, where it is seen that while in M. melanoptera and Z. auriculata these values were greater than 2, in Picui Ground Dove it was closer to one. This implies that a differential oxygen partial pressure of $7.5 \mathrm{Kpa}$, a usual value at sea level, it can hardly meet their maximal energy requirements. But this also means that Picui Ground Dove, would have serious limitations to live at high altitudes, where the differential in oxygen partial pressures may fall significantly. Interestingly this finding is consistent with the observation that Picui Ground Dove is found in lowlands and at the foot of low hills (Jaramillo).

ACKNOWLEDGEMENTS. We thank Lafayette Eaton for useful comments on a previous version of the manuscript. Claudio Veloso and Andres Sazo provided invaluable assistance in the field and the laboratory. Founded by FONDECYT 1080038 grant to MCL. 
Alfaro, C.; Figueroa, D. P.; SABAT, P.; SAllaberRY, M. \& CANALS, M. Comparación de la capacidad de difusión de oxígeno de la tórtola Picui (Columbina picui) con otras tórtolas de Chile. Int. J. Morphol., 28(1):127-133, 2010.

RESUMEN: Se estudió la densidad de superficie respiratoria y el espesor de la barrera sangre-aire en la Tortolita cuyana (Columbina picui), y se comparó con la Tórtola cordillerana (Metropelia melanoptera) y la Tórtola (Zenaida auriculata), dos especies más grandes. Como era de esperar, en $C$. picui el metabolismo basal y el metabolismo máximo fueron más altos que los de especies más grandes, pero de acuerdo a lo esperado para el tamaño corporal. La densidad de la superficie respiratoria y el espesor de la barrera sangreaire no fueron diferentes entre las diferentes especies de tórtolas. Sin embargo C. picui mostró un factor de difusión anatómica inferior a M. melanoptera y Z. auriculata. C. picui tuvo valores bajos de capacidad de difusión de oxígeno, como las aves cursoriales. A una diferencia de presión parcial de oxígeno de 7,5 Kpa, un valor habitual a nivel del mar, apenas podría satisfacer sus necesidades de energía máxima y esto significa que tendría serias limitaciones para vivir a gran altura, lo cual es coherente con la observación de que esta especie habita en las tierras bajas y en la zona precordillerana de los Andes.

PALABRAS ClAVE: Tórtola Picui, Columbina picui; Metropelia melanoptera; Zenaida auriculata; Difusión de oxígeno.

\section{REFERENCES}

Canals, M.; Iriarte-Díaz, J.; Olivares, R. \& Novoa, F. F. Comparación de la morfología alar de Tadarida brasiliensis (Chiroptera: Molossidae) y Myotis chiloensis (Chiroptera: Vespertilionidae), representantes de dos patrones de vuelo. Rev. Chil. Hist. Nat., 74:699-704, 2001.

Canals, M.; Grossi, B.; Iriate-Díaz, J. \& Veloso, C. Biomechanical and ecological relationships of wing morphology of eight chilean bats. Rev. Chil. Hist. Nat., 78:215-27, 2005a.

Canals, M.; Atala, C.; Olivares, R.; Guajardo, F.; Figueroa, D. P.; Sabat, P. \& Rosenmann, M. Functional and structural optimization of the respiratory system of the bat Tadarida brasiliensis (Chiroptera: Molossidae): does the airway geometry matter? J. Exp. Biol., 208:398795, $2005 b$.

Canals, M.; Atala, C.; Grossi, B. \& Iriarte-Díaz, J. Relative size of hearts and lungs of small mammals. Acta Chiropterol., 7(1):65-72, $2005 \mathrm{c}$.

Canals, M.; Donoso, C.; Figueroa, D. P. \& Sabat, P. Pulmonary hematological parameters, energetic flight demands and their correlation with oxygen diffusion capacity in the lungs. Rev. Chil. Hist. Nat., 80:275-84, 2007.

Canals, M.; Sabat, P. \& Veloso, C. The proximal airway of the bat Tadarida brasiliensis: a minimum entropy production design. J. Comp. Physiol. B., 178:378-84, 2008.

Fieldsa, J. \& Krabbe, N. Birds of the high Andes. Copenhagen, Apollo Books, Svendborg \& Zoological
Museum, 1990.

Figueroa, D. P.; Olivares, R.; Sallaberry, M.; Sabat, P. \& Canals, M. Interplay between the morphology of the lungs and the mode of locomotion in birds and mammals. Biol. Res., 40:193-201, 2007.

Frith, H. J.; Wolfe, T. O. \& Barker, R. D. Food of six species of Columbidae, in the genera Geopelia, Phaps, Geophaps and Petrophassa. Aust. Wildl. Res., 3:160-71, 1976.

Gehr, P.; Mwangi, D. K.; Ammann, A.; Maloiy, G. M. O.; Taylor, C. R. \& Weibel, E. R. Design of the mammalian respiratory system. V. Scaling morphometric pulmonary diffusing capacity to body mass: wild and domestic mammals. Respir. Physiol., 44:61-86, 1981.

Iriarte-Díaz, J.; Novoa, F. F. \& Canals, M. Biomechanic consequences of differences in wing morphology between Tadarida barsiliensis and Myotis chiloensis. Acta Theriol., 47(2):193-200, 2002.

Jaramillo, A. Birds of Chile. Princeton and Oxford, Princeton Field Guides, 2003. pp.240.

Maina, J. N. \& King, A. S. The structural functional correlation in the design of the bat lung. A morphometric study. J. Exp. Biol., 111:43-63, 1984.

Maina, J. N.; Thomas, S. P. \& Dalls, D. M. A morphometric study of bats of different size: correlations between structure and function of the chiropteran lung. Phil. Trans. Roy. Soc. London, B333:31-50, 1991. 
ALFARO, C.; FIGUEROA, D. P.; SABAT, P.; SALLABERRY, M. \& CANALS, M. Comparison of the oxygen diffusing capacity of the Picui Ground Gove (Columbina picui) with other doves of Chile. Int. J. Morphol., 28(1):127-133, 2010.

Maina, J. N. What it takes to fly: the structural and functional respiratory refinements in birds and bats. J. Exp. Biol., 203:25-44, 2000.

Maina, J. N. Some recent advances on the study and understanding of the functional design of the avian lung: morphological and morphometric perspectives. Biol. Rew., 77:97-152, 2002.

McNab, B. K. The influence of body mass, climate and distribution on the energetics of South Pacific pigeons. Comp. Biochem. Physiol. A., 127:309-39, 2000.

Peters, G. W.; Steiner, D. A.; Rigoni, J. A.; Mascilli, A. D.; Schnepp, R. W. \& Thomas, S. P. Cardiorespiratory adjustments of homing pigeons to steady wind tunnel flight. J. Exo. Biol., 208:3109-20, 2005.

Rosenmann, M. \& Morrison, P. L. R. Maximum oxygen consumption and heat loss facilitation in small homeotherms by $\mathrm{He}_{2}$. Am. J. Physiol., 226:490-5, 1974.

Schmidt-Nielsen, K. Scaling: why is animal size so important?. Cambridge, Cambridge University Press, 1984. p.105.

Steadman, D. W. The historic biogeography and community ecology of Polynesian pigeons and doves. J. Biogeogr., 24:737-53, 1997.

Weibel, E. R. Morphometric estimation of pulmonary diffusion capacity. Respir. Physiol., 11:54-75, 1970/71.

Weibel, E. R. Introduction. In Principles of Animal Design. The Optimization and Symmorphosis Debate. Weibel, E. R.; Taylor, C. R. \& Bolis, L. (Eds.). Cambridge, Cambridge University Press, 1998. pp.1-11.

Withers, P. C. Measurement of VO2, VCO2 and evaporative water loss with a flow-trough mask. J. Appl. Physiol., 42:120-33, 1977.

\author{
Correspondence to: \\ Mauricio Canals \\ Departamento de Ciencias Ecológicas \\ Facultad de Ciencias \\ Universidad de Chile \\ Casilla 653, Santiago \\ CHILE \\ Email: mcanals@uchile.cl
}

Received: 29-07-2009

Accepted: 12-12-2009 
